\title{
ZWIĄZKI PARTNERSKIE JAKO FORMA WSPÓŁPRACY JEDNOSTEK SAMORZAॄDU TERYTORIALNEGO W ŚWIETLE PRAWA KRAJOWEGO, UNIJNEGO I MIEDDZYNARODOWEGO
}

\begin{abstract}
Proces międzynarodowej współpracy samorządów jest wynikiem narodzin ruchu partnerskiego, który rozwinął się w Europie po II wojnie światowej. Partnerstwo miast, jako nowa forma oddolnych relacji międzynarodowych, w pierwszych latach swojego istnienia było zorientowane na przezwyciężanie skutków wojny. Miało się to dokonywać poprzez bezpośrednie spotkania mieszkańców gmin różnych krajów i rozwijać dzięki wspólnym inicjatywom kulturalnym czy sportowym. Bolesne doświadczenia powojenne, przesiedlenia, utrata bliskich oraz w konsekwencji zimna wojna, która podzieliła kontynent, sprawiły, że samo budowanie partnerstwa stało się warunkiem zmiany rzeczywistości. Początki były trudne $\mathrm{z}$ jednego prostego powodu. Żelazna kurtyna, która gospodarczo, politycznie i militarnie podzieliła świat, w założeniu jej twórców miała także powstać w ludzkich umysłach. Ludzie mieli pogodzić się z podziałem Wschód-Zachód i nie myśleć nad logiką i zasadnością takiego podziału. Wspólna Europa miała natomiast przede wszystkich łączyć mieszkańców.
\end{abstract}

\section{PRZESZKOŚĆ I PRZYSZŁOŚĆ MIĘDZYNARODOWEJ WSPÓŁPRACY MIAST}

Inicjatorami związków bliźniaczych byli merowie miast francuskich i burmistrzowie miast niemieckich, którzy po kilku udanych próbach stworzenia partnerstwa miast niemiecko-francuskich w 1951 r. w Genewie powołali do życia Radę Gmin i Regionów Europy (Council of European Municipalities and Regions, CEMR), a w deklaracji założycielskiej zapowiedzieli ,,tworzenie nowych form relacji między miastami i gminami, wcielającymi w życie ideę Europy obywateli" ${ }^{1}$. Kiedy w Europie rozwijał się ruch bliźniaczy, jego ojcowie musieli borykać się z licznymi trudnościami często o charakterze politycznym pozostałościami po konfliktach wojennych. Współcześnie nawiązanie współpracy niemiecko-francuskiej czy niemiecko-polskiej jest dużo prostsze, a władze gminne mają do dyspozycji wiele narzędzi krajowych i unijnych wspierających te działania.

\footnotetext{
${ }^{1}$ Deklaracja założycielska Rady Gmin i Regionów Europy, cyt. za: Wspótpraca partnerska samorzadów. Praktyczny przewodnik, Związek Miast Polskich, Poznań 2009, s. 4.
} 
Miasta partnerskie były także tworzone w ramach współpracy państw zwanych kiedyś socjalistycznymi. Współpraca sprowadzała się jednak głównie do wizyt dygnitarzy partyjnych rządzonych przez komunistów, dlatego dopiero ustrój demokratyczny, oparty na decentralizacji, stworzył warunki rozwoju rzeczywistej przyjaźni społeczności lokalnych.

Zaangażowanie gmin w sprawy zagraniczne jest istotnym aspektem polityki lokalnej. Jej głównym instrumentem jest partnerstwo miast, które w latach 50 . i 60. ubiegłego wieku zdaniem niemieckiej opinii publicznej stanowiło szansę na budowanie mostów pojednania oraz pomogło przezwyciężyć izolację Niemiec. Lokalne partnerstwo znalazło swoje miejsce w gminnej polityce i społeczeństwie oraz stało się silną częścią składową lokalnego życia. Przez pierwsze 20-25 lat po zakończeniu II wojny światowej ograniczano partnerstwo geograficznie, koncentrując się na Europie i skupiając na wymianie młodzieży oraz współpracy kulturalnej. Taka orientacja współpracy miast była jednak logiczna w związku z zadaniem zbliżania i pojednania narodów.

Obecnie lokalny ruch partnerski nie stoi w miejscu. Zmienił się i podejmuje nowe wyzwania. Zrozumienie dla lokalnego zaangażowania za granicą staje się coraz bardziej kompleksowe. Gminy udzielają się na arenie międzynarodowej, ponieważ w ramach swoich możliwości chca ponosić odpowiedzialność na rzecz rozwoju krajów Afryki, Azji i Ameryki Łacińskiej. Poprzez swoje zaangażowanie, wspólnie z innymi gminami, dążą do ponadgranicznej wymiany doświadczeń, a w międzynarodowych projektach szukają wspólnych rozwiązań wspólnych problemów. Międzynarodowa współpraca gmin jest przez to wewnętrznie bogatsza i kompleksowa geograficznie.

Międzynarodowe związki gmin stworzyły także społeczne podstawy integracji politycznej w Europie. Gospodarcze i polityczne zjednoczenie w europejskim społeczeństwie miało przeciwdziałać nowym uprzedzeniom i osadzać narodową politykę na szczeblu polityczno-instytucjonalnym. Założenia te, charakteryzujące się na wczesnym etapie porozumieniem „, dołu do góry”, nadały międzynarodowej współpracy mimo wszystkich politycznych konfliktów między Niemcami i Francją dużą dynamikę i pozostaja ważnym impulsem współpracy między gminami.

Współpraca międzynarodowa na szczeblu samorządowym jest $\mathrm{w}$ dobie globalizacji zjawiskiem o coraz większym znaczeniu. Mimo to ani polskie ustawodawstwo, ani prawodawstwo unijne nie operuja jednolitym nazewnictwem definiującym partnerską współpracę samorządów. Określenia stosowane w Europie typu „miasta partnerskie”, „miasta bliźniacze” bądź „twinning” lub amerykańskie ,sister cities” zostały wypracowane w toku wieloletnich doświadczeń.

\section{ROLA SAMORZADÓW LOKALNYCH W ROZWIĄZYWANIU PROBLEMÓW GLOBALNYCH}

Doświadczenia pięćdziesięciu lat partnerstwa gmin w Europie przyczyniły się do ewolucji samego zjawiska współpracy miast. Jean Bareth, jeden ze współzałożycieli Rady Gmin i Regionów Europy, definiując konieczność 
dwustronnej współpracy, powiedział: „związek bliźniaczy oznacza relację dwóch społeczności, które pragną rozwijać wspólne działania zmierzające do budowy Europy, rozwiązywania swych problemów i zacieśniania więzów przyjaźni" ${ }^{2}$. W powyższych celach współpracy miast wyróżniają się takie wartości, jak: przyjaźń, współpraca oraz zrozumienie narodów. Aksjologiczny aspekt partnerstwa miast miał zatem dominować nad jego politycznością. Początkowe trudności w budowaniu relacji bilateralnych nie pozwalały ojcom integracji na szczeblu lokalnym snuć marzeń o partnerstwie wielostronnym, dlatego też Jean Bareth mówił o relacji dwóch społeczności. Z dwustronnych związków wykształciły się z biegiem czasu także sieci, trój- lub wielostronnego partnerstwa i międzynarodowe konferencje burmistrzów, które pozwoliły na szeroką wymianę doświadczeń, kompleksową strukturę współpracy i bezpośrednią polityczną interwencję. Poza tym powstały liczne wspólne projekty w ramach programów UE, które doprowadziły do stabilności sieci. Ogromna rolę we współpracy większej grupy samorządów dostrzegł w 1989 r. Parlament Europejski, który zachęcił UE do łączenia miast bliźniaczych ${ }^{3}$. W 1989 r. Komisja Europejska uruchomiła program „,Town twinning” na finansowe wspieranie gmin $\mathrm{w}$ działaniach wprowadzających $\mathrm{w}$ życie ideę miast partnerskich.

Niektóre miasta $\mathrm{w}$ wyniku międzynarodowej działalności wypracowały własny międzynarodowy profil, w którym klasyfikuje się ich aktywność: Bonn jako europejska siedziba Organizacji Narodów Zjednoczonych i jako miasto, które zwołuje znaczące konferencje oraz odgrywa ważną rolę w międzynarodowych konferencjach burmistrzów; Norymberga jako miasto praw człowieka, Ludwigsburg jako miasto niemiecko-francuskich związków lub Hamburg jako „okno na świat”4.

Sama współpraca gmin uległa na przestrzeni lat ważnej ewolucji. Od pierwotnych obszarów współpracy opierających się niemal wyłącznie na współpracy kulturalnej i wymianie młodzieży w celu przełamywania stereotypów do współczesnego tworzenia partnerstwa bilateralnego i sieci miast zorientowanych na wspólne rozwiązanie globalnych problemów. Miasta musza jednak szukać nowych bodźców do bliźniaczych kontaktów, gdyż II wojna światowa powoli staje się odległym wspomnieniem i jest niewystarczającym powodem współpracy. Ciagle rozwijająca się Europa i wyzwania współczesnego świata sprawiają, że miasta partnerskie coraz częściej łączy nie wspólna historia, ale wspólna przyszłość. Implikuje to konieczność dostrzeżenia w gminach partnerów w działaniach na rzecz rozwoju i uwzględnienia znaczenia międzynarodowej działalności jednostek samorządu terytorialnego w przepisach prawnych.

Współpracę miast charakteryzuje intensywność i znaczenie międzynarodowych działań na szczeblu lokalnym i ich obecne formy. Rosnąca integracja gospodarcza, społeczna i polityczna wpływają pod wieloma względami także na

\footnotetext{
${ }^{2}$ Cyt. za: Wspótpraca partnerska samorzadów..., s. 6.

${ }^{3}$ Tworzenie tematycznych sieci miast blizniaczych, Luksemburg 2008, s. 3.

${ }^{4}$ A. Statz, Ch. Wohlfarth, Kommunale Partnerschaften und Netzwerke. Ein Beitrag zu einer transnationalen Politik der Nachhaltigkeit, Berlin 2010, s. 17.
} 
gminy. Jednolity rynek i polityka na europejskim szczeblu determinują możliwości rozwoju gmin, w szczególności w odniesieniu do użyteczności publicznej, środowiska i rozwoju miejskiego oraz regionalnego. Instytucjonalnie tworzy się wieloszczeblowy system, w którym gminy poprzez bezpośrednią współpracę z Komisją Europejską zyskują niezależność. Gminy zostały włączone do wielu programów pomocowych. Współpraca gmin stała się tym samym integralna częścią składową polityki UE.

W obliczu takich kompleksowych i zewnętrznych oczekiwań motywy i interesy leżące u podstaw lokalnych stosunków międzynarodowych mają wieloraką naturę. Obok spotkań lokalnych polityków, grup młodzieżowych, klubów sportowych, wymiany szkolnej i kulturowej, przyczyniających się niewatpliwie do zrozumienia narodów, szybko zaczęto interesować się wymianą doświadczeń, a później także wspólnymi projektami, przynoszącymi obustronne korzyści polityczne i gospodarcze. W utworzonych związkach partnerskich jednostek samorządu terytorialnego znalazły odzwierciedlenie wspólne motywy i interesy społeczeństwa obywatelskiego oraz gospodarki. Spowodowało to, że współpraca między gminami zyskiwała na znaczeniu. Nie byli w nią zaangażowani już tylko burmistrzowie i lokalni politycy ${ }^{5}$. Podmiotami międzynarodowych działań samorządów są bowiem z jednej strony władze lokalne, bez udziału których taka współpraca często nigdy nie zostałaby nawiązana, z drugiej najważniejszymi uczestnikami współpracy miast są obywatele, których zaangażowanie w wielu przypadkach decyduje o trwałości tej współpracy. Rola narodów w budowaniu wspólnej Europy znalazła potwierdzenie w licznych dokumentach. Jako przykład mogą posłużyć pierwsze artykuły Traktatu ustanawiającego Konstytucję dla Europy, który głosi, że Unia powstała z woli obywateli i państw Europy, żeby budować wspólną przyszłość, a głównym celem Unii jest ,„promowanie pokoju [...] i dobrobytu jej narodów" 6 .

Istotnym elementem rosnącej roli władz lokalnych jest ponadto spójność terytorialna polegająca na zintegrowanym rozwoju gospodarczym, społecznym i środowiska regionu, miasta i gminy. Połączenie strategii lokalnych, regionalnych, krajowych i europejskich ma przynieść korzyści społecznościom lokalnym dzięki kompleksowemu ujęciu otoczenia, w którym żyją ${ }^{7}$.

\section{PRAWNY WYMIAR MIĘDZYNARODOWEJ WSPÓŁPRACY MIAST}

\section{Prawodawstwo unijne}

$\mathrm{Na}$ poczatku lat 90. ubiegłego wieku proces integracji Polski z Unią koncentrował się na obszarach przygranicznych, w ramach współpracy transgranicznej. Sporadyczne początkowo kontakty między jednostkami samorządu

${ }^{5}$ J. Mikułowski-Pomorski, Międzynardowa wspótpraca gmin bliźniaczych, w: A. Skorupska (red.), Wspótpraca międzynarodowa samorzadu gminnego, Warszawa 2005, s. 76.

${ }^{6}$ Traktat ustanawiający Konstytucję dla Europy z 16 grudnia 2004 r., Dz. Urz. UE C310 z 16 grudnia 2004, s. 1 .

${ }^{7}$ Zielona Księga $w$ sprawie spójności terytorialnej. Przeksztatcenie różnorodności terytorialnej $w$ site, Komisja Wspólnot Europejskich, Bruksela 2008, COM (2008) 616, www.ec.europa.eu. 
terytorialnego stopniowo przybierały postać stałej i regularnej współpracy. Dało to początek euroregionom jako obszarom współpracy przygranicznej i transgranicznej opartym na porozumieniach lokalnych i regionalnych jednostek samorządu terytorialnego. Prawne usankcjonowanie współpracy transgranicznej wprowadziła Europejska konwencja ramowa o współpracy transgranicznej między wspólnotami i władzami terytorialnymi z 1980 r. (tzw. Konwencja madrycka). Polska ratyfikowała ją w 1993 r. Zgodnie z zapisami Konwencji współpracę transgraniczną należy definiować jako „każde wspólnie podjęte działanie mające na celu umocnienie i dalszy rozwój sassiedzkich kontaktów między wspólnotami i władzami terytorialnymi dwóch lub większej liczby umawiających się Stron, jak również zawarcie porozumień i przyjęcie uzgodnień koniecznych do realizacji takich zamierzeń" 8 . Współpraca transgraniczna jest jednak pojęciem szerszym niż euroregion, który jest tylko jej odmianą mająca charakter instytucjonalny, umieszczona na geograficznie wyznaczonym obszarze. Transgraniczność to sąsiadowanie ze sobą obszarów granicznych należących do kilku państw9 ${ }^{9}$.

$\mathrm{Na}$ podstawie Konwencji madryckiej wiele państw europejskich zaczęło w latach 90. zawierać umowy międzynarodowe ukierunkowane na współpracę transgraniczną. Prawny aspekt takiej współpracy Niemiec i krajów sąsiadujących konstytuuje traktat z Karlsruhe zawarty w 1996 r. między rządem niemieckim, rządem francuskim, rządem luksemburskim oraz Radą Federacji Szwajcarii dotyczący współpracy transgranicznej między samorządami terytorialnymi a władzami lokalnymi ${ }^{10}$. O progresywnym wymiarze tego dokumentu może świadczyć fakt, że wprowadził on tak zwane zrzeszenie lokalne do spraw współpracy transgranicznej, jako nową zinstytucjonalizowaną formę współpracy transgranicznej ${ }^{11}$.

Rola samorządów w polityce światowej oraz współpraca międzynarodowa samorządów lokalnych stanowią obecnie jeden z kluczowych obszarów aktywności instytucji europejskich i światowych. Konferencje poruszające współczesne wyzwania i problemy cywilizacyjne coraz częściej dostrzegają znaczenie gmin w ich rozwiązywaniu. Udział i konieczność zaangażowania gmin zostały podkreślone w licznych dokumentach europejskich i międzynarodowych. W Strategii UE na rzecz Afryki: europejsko-afrykański pakt na rzecz przyspieszenia rozwoju Afryki ${ }^{12}$ dostrzeżono konieczność wzmocnienia uprawnień samorządów lokalnych oraz podkreślono strategiczne znaczenie przykładów partnerstwa bliźniaczego między miastami Afryki i Europy w celu realizacji

\footnotetext{
${ }^{8}$ Europejska konwencja ramowa o współpracy transgranicznej między wspólnotami i władzami terytorialnymi sporządzona w Madrycie 21 maja 1980 r., Dz. U. 1993, Nr 61, poz. 287.

${ }^{9}$ S. Czarnow, Niektóre aspekty prawne wspótpracy transgranicznej $i$ euroregionów, „Państwo i Prawo" 1997, z. 10, s. 59.

${ }^{10}$ A. Bussmann, Dziesięć lat Traktatu z Karlsruhe. Umowa wzorcowa dla wspótpracy transgranicznej między Polska a Niemcami?, w: E. Albrecht, K. Nowacki (red.), Transgraniczna wspótpraca spoteczności i wtadz między Polska a Niemcami, Berlin 2006, s. 232.

${ }^{11}$ R. Formuszewicz, Umowa z Karlsruhe jako model wspótpracy transgranicznej, Warszawa 2004, s. 15 .

12 Strategia UE na rzecz Afryki: europejsko-afrykański pakt na rzecz przyspieszenia rozwoju Afryki, strategia przyjęta przez Radę Europejską w dniach 15-16 grudnia 2005 r., COM (2005) 0489.
} 
Milenijnych Celów Rozwoju (MCR), przyjętych w 2000 r. na szczycie Organizacji Narodów Zjednoczonych.

Milenijne Cele Rozwoju obejmują osiem celów jako zobowiązanie społeczności międzynarodowej, w tym także Polski, do redukcji ubóstwa i głodu, zapewnienia równego statusu kobiet i mężczyzn, poprawy stanu zdrowia, stanu edukacji, walki z AIDS, ochrony środowiska naturalnego oraz zbudowania globalnego partnerstwa między narodami na rzecz rozwoju ${ }^{13}$. Ten ostatni cel w szczególny sposób podkreśliła rezolucja Parlamentu Europejskiego z 2007 r. w sprawie samorządów i współpracy na rzecz rozwoju ${ }^{14}$. Rezolucja ta wskazuje na doświadczenia samorządów w zakresie rozwoju, które gminy zdobywaja między innymi poprzez partnerstwo $\mathrm{z}$ innymi samorządami. W rezolucji zaznaczono, że samorządy mają długoletnie doświadczenie w zakresie wspierania rozwoju i wiedzę we wszystkich dziedzinach rozwoju miejskiego i obszarów wiejskich oraz wykorzystuja te wartości poprzez tworzenie sieci solidarności na całym świecie. W tym samym dokumencie Parlament Europejski wzywa do ,ustanowienia światowej mapy zarządzania lokalnego, zawierającej spis projektów, podmiotów, budżetów zgromadzonych przez samorządy lokalne w świecie, w celu ułatwienia koordynacji, spójności i synergii pomiędzy różnymi partnerami władz lokalnych" ${ }^{15}$.

Aby w pełni zrozumieć drogę, jaka przeszła Europa w podkreśleniu roli władz lokalnych w kształtowaniu polityki kontynentu, należy cofnąć się do 25 marca 1957 r. Przyjęte wówczas traktaty rzymskie obejmujące Traktat o ustanowieniu Europejskiej Wspólnoty Gospodarczej i Europejskiej Wspólnoty Energii Atomowej stały się podstawą procesu integracji europejskiej, a w konsekwencji utworzenia Unii Europejskiej. Traktaty rzymskie, podpisane przez przywódców Francji, Niemiec, Włoch, Belgii, Holandii i Luksemburga, miały stać się fundamentem Europy pokoju, demokracji i dobrobytu. Jednak aksjologiczny wymiar wspólnej Europy siedem lat wcześniej zapoczątkowali burmistrzowie gmin niemieckich i francuskich, którzy postanowili podjąć działania na poziomie lokalnym zmierzające ku pojednaniu obywateli kontynentu. Znaczenie traktatów rzymskich dla rozwoju partnerstwa gmin i udziału władz lokalnych było $\mathrm{w}$ późniejszych czasach podkreślane wielokrotnie. W Deklaracji berlińskiej, przyjętej z okazji pięćdziesiątej rocznicy podpisania traktatów rzymskich, jej sygnatariusze podkreślili, że ,,jest wiele celów niemożliwych do osiągnięcia w pojedynkę - można je zrealizować tylko wspólnymi siłami. Unia Europejska, państwa członkowskie, ich regiony i struktury lokalne dzielą się zadaniami" ${ }^{16}$. Znaczenie traktatów rzymskich dla rozwoju partnerstwa miast podkreśliła także Końcowa deklaracja konferencji miast partnerskich na Rodos w 2007 r. Jej hasłem przewodnim było „Part-

\footnotetext{
${ }^{13}$ Milenijne Cele Rozwoju zostały opublikowane na stronie internetowej Organizacji Narodów Zjednoczonych: http://www.unic.un.org.pl/.

${ }^{14}$ Rezolucja Parlamentu Europejskiego z 15 marca 2007 r. w sprawie samorządów lokalnych i współpracy na rzecz rozwoju, rezolucja nr P6_TA(2007)0083.

${ }^{15}$ Ibidem.

${ }^{16}$ Deklaracja przyjęta $z$ okazji pięćdziesiatej rocznicy podpisania traktatów rzymskich 25 marca 2007 r., www.europa.eu
} 
nerstwo jutra". Uczestnicy konferencji w deklaracji odnieśli się do traktatów z 1957 r. jako ważnego czynnika budującego wspólnotę obywateli ${ }^{17}$.

Dla rozwoju partnerstwa miast niemieckich i francuskich największe znaczenie odegrał traktat elizejski zawarty między Francją i Niemcami 22 stycznia 1963 r., uważany za symbol niemiecko-francuskiego pojednania ${ }^{18}$. Traktat ten zakładał konsultacje obu krajów w najważniejszych kwestiach polityki zagranicznej. Ważnym elementem traktatu były postanowienia dotyczące oświaty i spraw młodzieży, które stały się podstawą współpracy w zakresie wymiany uczniów. Układ ten przełamał tradycyjną niechęć obu narodów, dając tym samym zachętę do zawierania związków partnerskich między niemieckimi i francuskimi jednostkami samorzadu terytorialnego.

Ważnym osiaggnięciem dla współpracy miast był przyjęty w grudniu $2007 \mathrm{r}$. traktat lizboński, który po raz pierwszy w historii traktatów europejskich docenił w sposób właściwy rolę demokratycznie wybranych władz lokalnych i regionalnych, mających realny wpływ na życie obywateli ${ }^{19}$. Współpraca miast partnerskich przekroczyła granice nie tylko geograficzne, lecz także obszarów współdziałania. Inicjatywy zmierzające do pokonywania wrogości i nienawiści narodów zostały zastąpione współdziałaniem w kwestii zmian klimatycznych, problemów gospodarczych czy zmian demograficznych.

W założeniach kontynuatorów myśli Jeana Baretha współczesne wyzwania, jakim muszą sprostać mieszkańcy Europy, wymagaja współpracy gmin, jako jednostek będących najbliżej obywateli. Ten wieloaspektowy wymiar współpracy miast podkreśliła Deklaracja końcowa oraz Rezolucja XXIV Zgromadzenia Ogólnego Rady Gmin i Regionów Europy z Malmö z 2009 r. ${ }^{20}$ Potrzebę transnarodowej aktywności gmin podkreśla między innymi preambuła: „Europa musi również zademonstrować te wartości - tolerancji, szacunku i otwartości, równości płci - na arenie międzynarodowej, by działać na rzecz pokoju i promować dialog między kulturami, rozwiązywać konflikty, walczyć z biedą i przyczyniać się do osiagania Milenijnych Celów Rozwoju. Wierzymy, że cele te mogą zostać osiągnięte przez wzmocnienie współpracy międzynarodowej i współpracę bliźniaczą pomiędzy miastami europejskimi i tymi w krajach rozwijających się, zwłaszcza w Afryce, oraz poprzez pełne zaangażowanie krajów w niezbędną pomoc publiczną dla rozwoju”"21.

\section{Ustawodawstwo krajowe}

Preambuła Konstytucji RP z 2 kwietnia 1997 r. podkreśla „potrzebę współpracy ze wszystkimi krajami”. Ten globalny charakter współpracy z jednej strony jest wyraźnym sygnałem do aktywności bez podziałów geograficznych,

${ }^{17}$ Deklaracja końcowa konferencji miast partnerskich $z$ Rodos $w$ dniach 10-12 maja 2007 r., www.ccre.org.

${ }^{18}$ K. Łastawski, Od idei do integracji europejskiej, Warszawa 2003, s. 187.

19 Traktat lizboński przyjęty w 2007 r., Dz. Urz. UE C 306 z 17 grudnia 2007 r.

${ }^{20}$ Deklaracja końcowa i rezolucja przyjęte podczas XXIV Zgromadzenia Ogólnego Rady Gmin i Regionów Europy Malmö 24 kwietnia 2009, www.ccre.org.

${ }^{21}$ Ibidem. 
a z drugiej doskonale odzwierciedla ,zasadę przychylności Polski dla procesów integracji europejskiej" ustaloną wyrokiem Trybunału Konstytucyjnego ${ }^{22}$.

W Konstytucji RP zasada samorządności została zapisana w art. 16, ust. 2, w myśl którego: „Samorząd terytorialny uczestniczy w sprawowaniu władzy publicznej. Przysługującą mu w ramach ustaw istotną część zadań publicznych samorząd wykonuje w imieniu własnym i na własną odpowiedzialność" 23 .

Ustawa zasadnicza nadała polskim samorządom prawo do międzynarodowej działalności mocą art. 172 ust. 2, w myśl którego ,jednostka samorządu terytorialnego ma prawo przystępowania do międzynarodowych zrzeszeń społeczności lokalnych i regionalnych oraz współpracy ze społecznościami lokalnymi i regionalnymi innych państw". Konstytucja RP regulacje tej współpracy odsyła do oddzielnej ustawy, jednak w istocie taka ustawa nie została przyjęta. W polskim systemie prawnym nie istnieje ustawa określająca zasady korzystania przez jednostki samorządu terytorialnego z prawa o współpracy ze społecznościami lokalnymi i regionalnymi innych państw. Ustawowo określone są jedynie zasady przystępowania jednostek samorządu terytorialnego do międzynarodowych zrzeszeń jednostek samorządu terytorialnego. Oznacza to, że współpraca między samorządami jest finansowana z publicznych pieniędzy, mimo że nigdy nie zostały ustawowo określone zasady takiej współpracy.

Zakładając, że proces integracji europejskiej cały czas realizuje się na poziomie gminnym i można go postrzegać w kategorii dyplomacji oddolnej, przepisy konstytucyjne dla współpracy gmin są kluczowe. Istotna jest również treść art. 9 Konstytucji RP, określająca przestrzeganie prawa międzynarodowego. Implikuje to dbałość jednostek samorządu terytorialnego o przepisy oraz obszary międzynarodowej działalności w oparciu o międzynarodowe prawo i standardy. Na tym tle szczególnie ważne są zasady nawiązywania międzynarodowej współpracy samorządu województwa.

Mimo że współpraca międzynarodowa gmin była rozwijana praktycznie od początku ich przywrócenia w 1990 r., to aż do 2000 r. nie była ona traktowana jako zadanie własne jednostek samorządu terytorialnego. Obecnie ustawodawca współpracę miast traktuje jako zadanie własne gminy zaspokajające zbiorowe potrzeby wspólnoty ${ }^{24}$. W artykule 84 a ustawodawca zapisał: ,Zasady przystępowania gminy do międzynarodowych zrzeszeń społeczności lokalnych i regionalnych określają odrębne przepisy" ${ }^{25}$. Wprowadzenie tego przepisu uregulowało kwestię zrzeszania się samorządów terytorialnych. Mimo że Konstytucja przyznaje jednostkom prawo, a nie wolność zrzeszania się, to jednak jest to znaczny postęp $\mathrm{w}$ przepisach prawa $\mathrm{w}$ porównaniu $\mathrm{z}$ ustawa konstytucyjną z 17 października 1992 r. Artykuł 75 tej ustawy głosił, że zasady zrzeszania się jednostek samorządu terytorialnego określa ustawa ${ }^{26}$. Przepis Konstytucji RP z 2 kwietnia 1997 r., przyznając prawo do zrzeszania, dał tym

${ }^{22}$ Wyrok Trybunału Konstytucyjnego z 25 maja 2003 r., K11/03, OTK 2003, seria A, nr 5, poz. 43.

${ }^{23}$ Konstytucja RP z 2 kwietnia 1997 r., Dz. U. 1997, Nr 78, poz. 483.

${ }^{24}$ Ustawa z 8 marca 1990 r. o samorządzie gminnym (art. 7), Dz. U. 2001, Nr 142, poz. 1591.

25 Ibidem.

${ }^{26}$ Ustawa konstytucyjna z 17 października 1992 r. o wzajemnych stosunkach między władzą ustawodawczą i wykonawczą Rzeczypospolitej Polskiej oraz o samorządzie terytorialnym, Dz. U. 1992, Nr 84, poz. 426. 
samym gwarancje ochrony tego prawa ${ }^{27}$. Dodatkowo nowelizacja ustawy o samorządzie gminnym z 2001 r. wprowadziła współprace ze społecznościami lokalnymi i regionalnymi innych państw jako zadanie własne ${ }^{28}$. Kompetencje rady gminy rozszerzyły art. 1 ust. 8 oraz art. 1 ust. 15 ustawy nowelizującej ustawę o samorządzie gminnym, o podejmowanie uchwał w sprawach współpracy ze społecznościami lokalnymi i regionalnymi innych państw oraz przystępowania do międzynarodowych zrzeszeń społeczności lokalnych i regionalnych. Przepis ten oraz powyższe określenie zadania własnego gminy zwracają uwagę na ważny aspekt udziału społeczności lokalnych w międzynarodowej aktywności gmin. Organy samorządu mają, jako zadanie własne, nawiązywać taką współpracę, jednak głównym beneficjentem korzyści oraz podmiotem uczestniczącym mają być społeczności lokalne. Zasada ta jest spójna z akcentowaniem roli obywateli w budowaniu wspólnej Europy podkreślona w Konstytucji RP.

Polskie samorządy, szczególnie gminne, bardzo szybko dostrzegły szanse rozwojowe związane ze współpraca z gminami Europy Zachodniej. W okresie transformacji ustrojowej partnerstwo polsko-niemieckie cieszyło się ogromna popularnością. Było to związane $\mathrm{z}$ doświadczeniami politycznymi i gospodarczymi tamtejszych samorządów oraz ich zainteresowaniem współpraca z gminami państw postkomunistycznych. Ponad 90\% istniejacych kontaktów bliźniaczych w Polsce zostało nawiązanych po 1989 r. ${ }^{29} \mathrm{~W}$ okresie integracji Polski z UE kwestia współpracy zagranicznej samorządów nabrała szczególnego znaczenia. Nowe wyzwania, jakim musiało sprostać państwo polskie, bardzo często dotyczyły także spraw będących w kompetencji samorządów. Dostosowanie się do wymogów europejskich oraz zdobycie wszechstronnego doświadczenia w efektywnym korzystaniu $\mathrm{z}$ unijnych programów pomocowych wymagały wzajemnej partnerskiej edukacji z samorządami terytorialnymi krajów Unii.

Przepisy dotyczące międzynarodowej współpracy zostały także wprowadzone do ustawy o samorządzie powiatowym. Ustawa z 21 stycznia $2000 \mathrm{r}$. przyznała radzie powiatu kompetencje $\mathrm{w}$ zakresie podejmowania uchwał o współpracy ze społecznościami lokalnymi innych państw oraz o przystępowaniu do międzynarodowych zrzeszeń społeczności lokalnych ${ }^{30}$. Istotne jest jednak zwrócenie uwagi na fakt, że ustawa o samorządzie gminnym nadaje radzie gminy prawo podejmowania uchwał w sprawie współpracy ze społecznościami lokalnymi i regionalnymi, podczas gdy ustawa o samorządzie powiatowym ogranicza kompetencje rady powiatu tylko do współpracy ze społecznościami lokalnymi.

Spośród aktów prawa miejscowego, tworzonego przez lokalnych polityków, podstawą międzynarodowej współpracy jest uchwała rady miasta lub rady

\footnotetext{
${ }^{27}$ P. Suski, Stowarzyszenia i fundacje, Warszawa 2005, s. 70.

${ }^{28}$ Ustawa z 11 kwietnia 2001 r. o zmianie ustaw: o samorządzie gminnym, o samorządzie powiatowym, o samorządzie województwa oraz o administracji rządowej w województwie oraz o zmianie niektórych innych ustaw, Dz. U. 2001, Nr 45, poz. 497.

${ }^{29}$ E. Pancer-Cybulska, Uwarunkowania procesu integracji Polski $z$ Unia Europejska na poziomie regionalnym i lokalnym, Wrocław 2005, s. 182.

${ }^{30}$ Ustawa z 21 stycznia 2000 r. o zmianie niektórych ustaw związanych z funkcjonowaniem administracji publicznej, Dz. U. 2000, Nr 12, poz. 136.
} 
gminy o nawiązaniu współpracy $\mathrm{z}$ zagraniczną jednostką terytorialną. Najważniejsze dokumenty gminne ustanawiające międzynarodowe kontakty to podpisana umowa partnerska, deklaracja o partnerstwie lub list intencyjny oraz uchwała rady potwierdzająca ten fakt.

Przywrócenie samorządu na szczeblu województwa sprawiło, że obok wojewody nowym podmiotem współpracy międzynarodowej stał się samorząd województwa ${ }^{31}$. Jednocześnie wzrosła ranga województwa jako regionu, co implikowało uznanie regionów za jeden z najważniejszych podmiotów współpracy zagranicznej. Zagadnienie międzynarodowej współpracy polskich regionów zostało ujęte w ustawie o samorządzie województwa, a podstawową rolę w tym zakresie odgrywa sejmik ${ }^{32}$.

W ustawie o samorządzie województwa współpraca zagraniczna została zorientowana wprost na współpracę ze społecznościami regionalnymi, a nie lokalnymi. Sejmik województwa, mocą ustawy, uzyskał wyłączne uprawnienia związane $\mathrm{z}$ podejmowaniem uchwał dotyczących współpracy zagranicznej: „Priorytety współpracy zagranicznej województwa”, w której określa główne cele, priorytety geograficzne oraz perspektywy współpracy zagranicznej ${ }^{33}$, oraz $\mathrm{w}$ sprawie podjęcia inicjatyw zagranicznych ${ }^{34}$. Obie te uchwały, zapadające bezwzględną większością głosów ustawowego składu sejmiku, muszą być podjęte za zgodą Ministra Spraw Zagranicznych. Sejmik i Minister są organami współpracującymi przy podejmowaniu współpracy zagranicznej przez województwo ${ }^{35}$. Z jednej strony, bez uchwały sejmiku współpraca nie może zostać podjęta, natomiast z drugiej odmowa wydania zgody przez Ministra na zainicjowanie takiej współpracy sprawia, że podjęta uchwała jest nieważna. Nadzór nad współpraca zagraniczna prowadzoną przez województwo nakłada ponadto na państwo odpowiedzialność za tę współpracę.

Artykuł 41 ust. 2 pkt 5 ustawy o samorządzie województwa ,organizowanie współpracy ze strukturami samorządu regionalnego w innych krajach i z międzynarodowymi zrzeszeniami regionalnymi" na podstawie przyjętych przez sejmik uchwał traktuje jako zadanie zarządu województwa. Tym samym zarząd jest zobowiązany wykonać podjęte przez sejmik uchwały, sam sejmik nie ma jednak obowiązku podejmowania takich uchwał, kierując się $\mathrm{w}$ tym względzie własnym uznaniem.

Szczegółowe wytyczne międzynarodowej współpracy polskich samorządów zostały uregulowane w ustawie z 15 września 2000 r. o zasadach przystępowania jednostek samorządu terytorialnego do międzynarodowych zrzeszeń społeczności lokalnych i regionalnych ${ }^{36}$. Ustawodawca nadał jednostkom samorządu terytorialnego prawo przystępowania do zrzeszeń społeczności lokalnych i regionalnych, określając jednocześnie, że granice tej współpracy

${ }^{31}$ M. Woźniak, Wspótpraca międzynarodowa jednostek samorzadu terytorialnego w świetle prawa polskiego i standardów międzynarodowych, ,Samorząd Terytorialny” 2005, nr 4, s. 20.

${ }^{32}$ Ustawa o samorządzie województwa, Dz. U. 2001, Nr 142, poz. 1590.

${ }^{33}$ Art. 75 ustawy o samorządzie województwa.

${ }^{34}$ Art. 18 pkt 13 i 14 ustawy o samorządzie województwa.

35 S. Czarnow, Wspótpraca zagraniczna województw, „Państwo i Prawo” 2000, z. 11, s. 57-58.

${ }^{36}$ Ustawa o zasadach przystępowania jednostek samorządu terytorialnego do międzynarodowych zrzeszeń społeczności lokalnych i regionalnych z 15 września 2000 r., Dz. U. 2000, Nr 91, poz. 1009. 
wyznaczają kompetencje jednostek samorządu terytorialnego, polskie prawo wewnętrzne, polityka zagraniczna państwa oraz jego międzynarodowe zobowiązania $^{37}$.

Uchwałę $\mathrm{w}$ sprawie przystapienia samorządu do zrzeszenia międzynarodowego podejmuje organ stanowiący bezwzględną większością głosów. Uchwała trafia do wojewody, który po dołączeniu swojej opinii przekazuje ją Ministrowi Spraw Zagranicznych. Ministrowi doręcza się także statut zrzeszenia, listę jego członków oraz urzędowe tłumaczenie tych dokumentów na język polski. Sejmik województwa dodatkowo przedstawia „Priorytety współpracy zagranicznej województwa”. Minister zgodę na przystąpienie do zrzeszenia lub odmowę takiej zgody podejmuje w drodze decyzji administracyjnej. Po uzyskaniu zgody ministra uchwała wchodzi w życie.

Prawne regulacje określające zasady prowadzenia współpracy zagranicznej przez samorząd województwa zawarte sa nie tylko w prawie wewnętrznym, lecz także w licznych dokumentach międzynarodowych ratyfikowanych przez Polskę.

Charakter prawny samorządu terytorialnego utorowała Światowa deklaracja samorządu lokalnego uchwalona podczas 27 Światowego Kongresu Międzynarodowego Związku Władz Lokalnych w Rio de Janeiro w 1985 r. Zgodnie z jej przepisami ,samorząd lokalny oznacza prawo i powinność władz lokalnych do lokalnego regulowania i zarządzania sprawami publicznymi dla dobra społeczności lokalnej" ${ }^{38}$. Podkreślono ponadto, że zarówno zasada samorządu lokalnego, jak i podstawowe kompetencje władz lokalnych powinny zostać zapisane $\mathrm{w}$ konstytucji lub ustalone $\mathrm{w}$ drodze ustawowej. $\mathrm{W}$ podobnym tonie wypowiada się Europejska karta samorządu lokalnego uchwalona 15 października $1985 \mathrm{r}^{39}$ Dokument ten jest uznawany za konstytucję samorządności lokalnej. Zwraca ona szczególną uwagę na rolę samorządu jako podstawy do budowania wspólnej Europy opartej na demokracji i decentralizacji władzy. Jednym z najważniejszych postanowień Karty, podobnie jak Światowej deklaracji samorządu lokalnego, jest nadanie zasadzie samorządności lokalnej rangi konstytucyjnej.

Przepisy dotyczące prowadzenie współpracy zagranicznej przez samorząd województwa reguluje nie tylko wspomniana już Europejska karta samorządu lokalnego, lecz także Konwencja madrycka oraz Europejska karta regionów granicznych i transgranicznych ${ }^{40}$. Karta powstała w 1981 r., przez Polskę została przyjęta w 1995 r. Do 1995 r. nosiła nazwę Europejska karta regionów przygranicznych. Na zebraniu Stowarzyszenia Europejskich Regionów Granicznych w Szczecinie w Euroregionie Pomerania, 1 grudnia 1995 r., zmieniono

\footnotetext{
37 Ibidem.

${ }^{38}$ Polski tekst Światowej deklaracji samorządu lokalnego został opublikowany we wkładce do dwutygodnika „Gospodarka-Administracja Państwowa” nr 21 z października 1988 r.

${ }^{39}$ Europejska karta samorządu lokalnego (przyjęta 15 października 1985 r. w Strasburgu), Dz. U. 1994, Nr 124, poz. 607 i 608. Dokument został przyjęty jako Europejska karta samorządu terytorialnego, jednak obwieszczeniem Ministra Spraw Zagranicznych z 22 sierpnia 2006 r. o sprostowaniu błędu (Dz. U. 2006, Nr 154, poz. 607) została zmieniona na Europejską kartę samorządu lokalnego.

${ }^{40}$ Europejska karta regionów granicznych i transgranicznych z 20 listopada $1981 \mathrm{r}$., www. msz.gov.pl.
} 
nazwę na obecną oraz uaktualniono tekst Karty pod kątem nowej sytuacji geopolitycznej w Europie Środkowo-Wschodniej. Karta precyzuje zamierzenia i cele rozwoju regionów granicznych i transgranicznych. Szczególną uwagę poświęcono problemom rozwoju ekonomicznego, polityki regionalnej, ochrony środowiska, współpracy kulturalnej, zagospodarowania przestrzennego i przygranicznemu ruchowi osobowemu. Karta nie stanowi międzynarodowego aktu prawnego i nie ma mocy obowiązującej. Stanowi jedynie formę deklaracji współpracy i jest swego rodzaju kodeksem postępowania współpracy transgranicznej. W preambule Karty napisano, że granice sa „,bliznami historii”, zatem rola sygnatariuszy dokumentu jest przezwyciężanie niekorzystnych skutków ich istnienia. Poznanie sąsiada i zrozumienie dla jego odrębności są równorzędnymi zadaniami w procesie budowania partnerstwa i współpracy, co samo budowanie zaufania.

\section{Prawodawstwo międzynarodowe}

W praktyce ruch miast partnerskich jest przykładem realizacji bilateralnych traktatów zawieranych między krajami. Współpraca miast polsko-niemieckich jest zatem realizacja art. 12 traktatu zawartego między Polską a Niemcami 17 czerwca 1991 r. w Bonn. Artykuł ten mówi: „Umawiające się Strony przywiązują duże znaczenie do partnerskiej współpracy między regionami, miastami, gminami i innymi jednostkami terytorialnymi, w szczególności na obszarach przygranicznych" ${ }^{41}$. Analogicznie partnerskie kontakty jednostek terytorialnych Polski i Białorusi sa praktyczna realizacja traktatu polsko-białoruskiego, zawierającego między innymi, zapis: „Umawiające się Strony będą sprzyjać ustanowieniu i rozwojowi bezpośrednich kontaktów i współpracy między regionami, miastami i innymi jednostkami administracyjno-terytorialnymi Rzeczypospolitej Polskiej i Republiki Białoruś [...]"42.

Międzynarodowa obecność jednostek samorządu terytorialnego jest zjawiskiem dynamicznym i aktywnie wspieranym przez instytucje europejskie. Międzynarodowa działalność gmin i powiatów ma zbliżać do siebie mieszkańców Europy, budować wspólną tożsamość oraz kształtować poczucie przynależności do obywatelstwa europejskiego. Aby państwa i jednostki samorządu terytorialnego mogły realizować te założenia, konieczne jest istnienie formalnoprawnych uwarunkowań określających przedmiot, podmiot oraz zakres międzynarodowego wymiaru samorządów.

Zakres regulacji samorządności $\mathrm{w}$ ustawach zasadniczych państw europejskich jest jednak zróżnicowany. W Konstytucji Republiki Francuskiej $\left(\right.$ art. 72) ${ }^{43}$ oraz w Konstytucji Republiki Federalnej Niemiec (art. 26 ust. 2) ) $^{44}$

41 Traktat między Rzecząpospolitą Polską a Republiką Federalną Niemiec o dobrym sąsiedztwie i przyjaznej współpracy, Bonn 17 czerwca 1991 r., w: Z. Leszczyński, A. Koseski (red. i oprac. nauk.), Stosunki międzynarodowe. Wybór tekstów źródtowych i materiatów 1989-2000, Pułtusk 2001, s. 102 (art. 12).

${ }^{42}$ Traktat między Rzecząpospolitą Polską a Republiką Białoruś o dobrym sąsiedztwie i przyjaznej współpracy, Warszawa 21 czerwca 1992 r., w: Z. Leszczyński, A. Koseski (red.), op. cit., s. 212 (art. 11).

${ }^{43}$ Konstytucja Francji z 4 października 1958 r. (wedtug stanu prawnego na dzień 22 lutego 1996 r.), tłum. W. Skrzydło, Warszawa 1997.

${ }^{44}$ Konstytucja Niemiec, oprac. S. Bożyk, Warszawa 1993. 
zawarta jest tylko ogólna zasada, podczas gdy Konstytucja Konfederacji Szwajcarskiej przedstawia szczegółowo organizację i funkcjonowanie terytorialnych związków samorządowych ${ }^{45}$.

Gminy pełnią podwójną rolę. Z jednej strony stanowią „lokalne państwo” $\mathrm{z}$ własnym terytorium, lokalnymi podatkami, prawem miejscowym oraz bogatym dorobkiem kulturalnym i historycznym, a z drugiej stwarzają możliwości rozwoju życia społeczno-politycznego w lokalnych warunkach. Taka niezależność gmin została podkreślona między innymi w art. 28 ust. 2 Konstytucji Republiki Federalnej Niemiec, który głosi, że ,gminom musi być zapewnione prawo regulowania wszystkich spraw lokalnych na własna odpowiedzialność i w ramach obowiązujących ustaw" 46 .

\section{PODSUMOWANIE}

Międzynarodowa współpraca miast w założeniach twórców tego ruchu miała zbliżać do siebie narody. Wsparciem podejmowanych przez nie działań powinny być władze samorządowe, które są najbliżej obywateli. Bliskość ta umożliwia rozwój aktywności społecznej, działanie na rzecz wspólnoty samorządowej oraz zbliżanie do siebie innych narodowości. Aktywne uczestnictwo w życiu społecznym miast partnerskich pozwala na propagowanie wartości, bez których każdy człowiek czuje się zagrożony. Bezpieczeństwo, sprawiedliwość, tolerancja, szacunek i wolności to główne idee, które powinny przyświecać ruchowi miast bliźniaczych. Jest to jednak możliwe tylko wówczas, gdy partnerstwo miast nie ogranicza się do wyjazdów lokalnych polityków i samorządowców oraz gdy nie ma wyłącznie politycznego charakteru. Każda zmiana polityczna może bowiem zagrozić współpracy, co jest dowodem braku włączania obywateli w budowanie partnerstwa samorządów. Przyjaźnie mieszkańców powinny być wolne od kadencyjności władz i tylko takie rozumienie idei współpracy stwarza szansę na prawdziwe partnerstwo miast. Udział władz lokalnych powinien być obecny zatem tylko na zasadzie subsydiarności wobec mieszkańców.

Ustawodawstwo krajowe powinno stwarzać możliwości prawne do zawierania i zacieśniania współpracy miast, a prawodawstwo unijne oraz międzynarodowe wskazywać dobre praktyki dla takich inicjatyw. Sytuacja, w której współpraca miast staje się przedmiotem politycznych rozgrywek, szybko doprowadzi do braku zaufania do władz lokalnych oraz do samej idei związków partnerskich jednostek samorządu terytorialnego.

mgr Emilia Kalitta

\footnotetext{
${ }^{45}$ Konstytucja Federalna Konfederacji Szwajcarskiej z dnia 18 kwietnia 1999 r., oprac. Z. Czeszejko-Sochacki, Warszawa 2000.

${ }^{46}$ Ustawa zasadnicza dla Republiki Federalnej Niemiec z 23 maja 1949 r., http://www. warschau.diplo.de/contentblob/1710226/Daten/146068/Grundgesetz_dl_PL.pdf.
} 


\section{TOWN TWINNING AS A FORM OF COLLABORATION BETWEEN LOCAL AUTHORITIES IN THE LIGHT OF THE DOMESTIC AND EUROPEAN LAW}

\section{Summary}

The term 'town twinning' and 'twin cities' was coined when municipalities (gminy) became active in the international arena. The precursors of the twinning movement were German and French communes which after World War II embarked on the task of bringing the two nations together. The twinning movement in its original form was primarily based on the exchange of the youths of both countries. Today, contacts between cities focus on economic and environmental cooperation, collaboration in the sphere of education and consolidation of activities fostering further development of partnership.

International cooperation of municipalities, while an important factor in the development of local politics, is not satisfactorily regulated. Neither the national nor the EU legislation contains the term 'twin cities' in its legal vocabulary. Constitutions, executive acts, declarations and treaties set out the essence of local government and law, but fail to specify the rules of a local foreign policy. This aspect is largely left to the decision of municipalities, which clearly emphasises the principle of self-government. EU directives do not define any rigid framework of international cooperation of communes either, merely emphasising their role in the shaping of that policy. Consequently, the role of municipalities in the solving of contemporary civilisation problems has been highlighted in final declarations adopted at twin cities congresses held in recent years. The absence of a legal framework at a higher level does not only mean that local municipalities are not restricted from developing their local foreign policies, but it also opens up for them numerous possibilities of cooperation in any area of their choice. 